\title{
A Spanish Version of the Achievement Task Value Scale for University Students: Internal, Convergent, and Criterion Validity and Reliability in Argentinian Students
}

\author{
Javier Sánchez-Rosas*, Yu-Chiung Lou**, Hsiao-Fang Lin ${ }^{\star * *}$, Silvana Larroza ${ }^{\star * * *}$
}

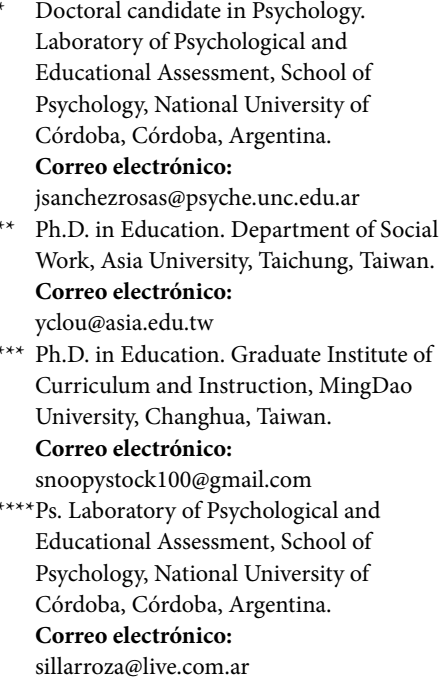

Recibido: 20 de septiembre del 2016 Aprobado: 17 de diciembre del 2016

Cómo citar este artículo: Sánchez-Rosas, J., Lou, Y. C., Lin, H. F. \& Larroza, S. (2017). A Spanish version of the Achievement Task Value Scale for University Students: Internal, convergent, and criterion validity and reliability in Argentinian students. Pensando Psicología, 13(21), 41-57. doi: http://dx.doi. org/10.16925/pe.v13i21.1713

\begin{abstract}
Objective: An Achievement Task Value Scale Spanish Language Adjusted Version, assessing task value items corresponding to importance, utility, interest and cost, was evaluated regarding its psychometric properties, in a sample of Argentine students. Method: In order to assess internal structure, exploratory and confirmatory strategies have been used. Besides, scale convergence was assessed by relating them with a one-dimensional task value scale. Evidences of criterion validity were supported by relating scales with enjoyment, achievement goals, and attention. Finally, internal consistency was estimated using Cronbach's Alpha and Omega coefficients. Conclusions: Results allow to state that this version of the instrument makes it possible to assess, in a reliable and valid way, three components of task value: utility, interest, and cost.
\end{abstract}

Keywords: achievement goals, attention, enjoyment, expectancyvalue theory, scale, task value. 


\title{
Una versión en español de la Achievement Task Value Scale for University Students: fiabilidad y validez interna, convergente y de criterio en estudiantes argentinos
}

\begin{abstract}
Objetivo: se evaluó una versión ajustada al idioma español de la Achievement Task Value Scale, la cual evalúa los ítems valorativos de tareas que corresponden a importancia, utilidad, interés y costo, con respecto a sus propiedades psicométricas en una muestra de estudiantes argentinos. Método: para evaluar la estructura interna se utilizaron estrategias exploratorias y de confirmación. Además, la convergencia de la escala se evaluó relacionándola con una escala valorativa unidimensional de tareas. Las evidencias de la validez de criterio se sustentaron relacionando las escalas con disfrute, metas de progreso y atención. Finalmente, la consistencia interna se estimó utilizando los coeficientes Alpha y Omega de Cronbach. Conclusiones: los resultados permiten afirmar que esta versión del instrumento hace posible evaluar de manera confiable y válida tres componentes valorativos de la tarea: utilidad, interés y costo.
\end{abstract}

Palabras clave: metas de progreso, atención, disfrute, teoría de valor-expectativa, escala, valor de la tarea.

\section{Uma versão em espanhol da Achievement Task Value Scale for University Students: confiabilidade e validade interna, convergente e de critério em estudantes argentinos}

\section{Resumo}

Objetivo: foi avaliada uma versão adaptada a espanhol da Achievement Task Value Scale, a qual avalia os itens valorativos de tarefas que correspondem a importância, utilidade, interesse e custo, a respeito de suas propriedades psicométricas numa amostra de estudantes argentinos. Método: para avaliar a estrutura interna, foram utilizadas estratégias exploratórias e de confirmação. Além disso, a convergência da escala foi avaliada relacionando-a com uma escala valorativa unidimensional de tarefas. As evidências da validade de critério foram apoiadas relacionando as escalas com deleite, metas de progresso e atenção. Finalmente, a consistência interna foi estimada utilizando os coeficientes Alpha e Ômega de Cronbach. Conclusões: os resultados permitem afirmar que essa versão do instrumento torna possível avaliar, de maneira confiável e válida, três componentes valorativos da tarefa: utilidade, interesse e custo.

Palavras-chave: metas de progresso, atenção, deleite, teoria de valor-expectativa, escala, valor da tarefa. 


\section{Introduction}

The degree to which a task is able to satisfy needs, facilitate attainment of goals, or reaffirm personal values determines the value a person assigns to a task in order to get involved in it (Eccles, 2005; Wigfield \& Eccles, 1992). From the Expectancy-Value Theory, it is proposed that the environment's efforts to influence task value will have an effect on students' achievements (Atkinson, 1957; Eccles et al., 1983; Wigfield, 1994; Wigfield \& Eccles, 1992). In this sense, several interventions have shown its positive effects on the task value perceived by individuals (Harackiewicz, Rozek, Hulleman, \& Hyde, 2012; Hulleman, Godes, Hendricks, \& Harackiewicz, 2010; Hulleman \& Harackiewicz, 2009; Hulleman, Kosovich, Barron, \& Daniel, 2016; Lee Johnson \& Sinatra, 2013; Pang, 2014; Rozek, Hyde, Svoboda, Hulleman, \& Harackiewicz, 2014; Schukajlow et al., 2012).

These interventions, designed to promote some of the components of task value, typically use ad hoc questionnaires in pre- and post-tests to assess changes after an intervention has been implemented (Harackiewicz et al., 2012; Hulleman et al., 2010; Hulleman \& Harackiewicz, 2009; Lee Johnson \& Sinatra, 2013), without developing specific studies on scale building. This also occurs in empirical research analyzing relationships between task value and other constructs such as motivation, emotions, instruction, coping and learning strategies, cognitive resources, engagement, or academic performance (Acee \& Weinstein, 2010; Jones, Johnson, \& Campbell, 2015; Sánchez-Rosas, 2015a, 2015b; Sánchez-Rosas \& Bedis, 2015; Sánchez-Rosas \& Esquivel, 2016; Sánchez-Rosas \& Pérez, 2015; Sánchez-Rosas, Takaya, \& Molinari, 2016b). Furthermore, studies do not usually include instruments using all of the task value components (Durick, Hulleman, \& Harackiewicz, 2014; McCoach \& Siegle, 2002; Rozek et al., 2014).

The Achievement Task Value Scale for University Students (Lou, Lin, \& Lin, 2012) was designed to assess the four components of task value as proposed by Eccles et al. (1983). Based on the satisfactory psychometric results obtained for the instrument, this questionnaire seems appropriate for studies that need to estimate the four components of task value.

This paper analyzes the psychometric properties of the Achievement Task Value Scale for University Students (Lou et al., 2012) in a sample of Argentinian students. Specifically, evidence of internal, convergent, and criterion validity, and internal consistency is provided.

\section{Task Value Components}

Atkinson (1957) defined task value in terms of incentive of anticipated success. Task value has been defined too as perceived importance, utility and interest of learning materials and academic contents (Pintrich, Smith, García, \& McKeachie, 1993). On the other hand, task value is considered by Wigfield and Eccles (2000) as the incentive for getting involved into academic activities.

Eccles et al. (1983) have proposed four components comprised in subjective task value: importance, interest, utility and cost.

The importance component is defined as the importance of succeeding at a particular task. To Wigfield and Eccles (2000), the importance of a task is how well it fits a person's identity. When a task is set to a student's identity, it will be very important to him. Conversely, when a task does not match the identity of an individual, it will be less relevant. For example, a student who has participated in mathematical olympiads may think that achievements in language-related tasks are not significant to be a good student. Consequently, language will be perceived by the student as having a low level of importance.

Interest relates to pleasure and enjoyment experienced while participating in activities (Eccles \& Wigfield, 2002). Hidi and Baird (1986) and Schiefele (1999) found that some tasks have certain characteristics that arouse the interest of students. First, tasks that are relevant to everyday life and provide pleasure and successful experiences generate interest. Second, tasks that provide sense of autonomy and are compatible with other interests tend to get individuals interested. Finally, when students internalize the values of people they meet, they can spend more time studying.

The utility component refers to the association of a task with short- or long-term objectives, and with positive consequences of the activity (Eccles \& Wigfield, 2002). For example, tasks that are strongly related to an individual's career have a higher utility value. Therefore, some students learn a subject due to its relationship with their future goals, rather than a personal interest in the subject.

The concept of cost includes comparisons among possible consequences of decisions. Cost refers to what individuals must give up to engage in a task. Factors comprised in cost are effort required to succeed, costs 
of failure to choose other valuable options, psychological cost resulting from failure, perception of difficulty, and so on (Eccles, 1987; Eccles et al., 1983; Eccles \& Wigfield, 1995; Wigfield \& Eccles, 1992, 2000).

\section{Task Value, Enjoyment, Achievement Goals and Attention}

While task value is considered as the incentive to engage in academic activities (Wigfield \& Eccles, 2000), consequences thereof can be expected from different expressions of student engagement in class (Fredricks, Blumenfeld, \& Paris, 2004).

Several studies suggest a relationship between task value and enjoyment. Task value is a quality of the task that contributes to the increasing or decreasing likelihood that an individual engages in it (Eccles, 1987; Eccles et al., 1983; Wigfield \& Eccles, 1992), and enjoyment is an emotion that arises during achievement activities or tasks (Pekrun, 2006). Pekrun (2006) states that if an activity is perceived as positively valued enjoyment is instigated. That is, if a student perceives that a task is important or interesting, he will feel enjoyment during it. The results of some studies (Pekrun, Goetz, Frenzel, Barchfeld, \& Perry, 2011; Sánchez-Rosas et al., 2016b) show that task value correlates positively with enjoyment in class.

On the other hand, task value is also related to achievement goals. Achievement goals are cognitive representations of objectives or results which people seek to approach or avoid in achievement contexts (Elliot \& Fryer, 2008). Wigfield (1994) and Miller and Brickman (2004) state that value appraisals about an academic task have implications on students' achievement goals, which is in line with Elliot's assumptions (1999) on motivation and achievement goals. Following these assumptions, Liem, Lau and Nie (2008) verified that there is a direct effect of task value on mastery goals, when they are measured as approach mastery goals.

Finally, research conducted by Pekrun, Goetz, Daniels, Stupinsky and Perry (2010) states that task value is positively related to a person's attentional level. Thus, if a task is perceived as important, useful, interesting or having some benefit, such task is likely to activate and focus attention on itself (Sánchez-Rosas \& Esquivel, 2016; Sánchez-Rosas, Takaya, \& Molinari, 2016a). For example, the more math exercises are perceived as useful because they can be used to pass an exam, the more the students will pay attention to them.

\section{Task Value Measurement}

As mentioned, interventions on task value often use questionnaires that are drafted for the research in question (Harackiewicz et al., 2012; Hulleman et al., 2010; Hulleman \& Harackiewicz, 2009; Lee Johnson \& Sinatra, 2013). For example, the study of Harackiewicz et al. (2012) aimed to assess an intervention designed to help parents to convey the importance of math and science courses for school-age children, which resulted in children taking more math and science courses in high school. In this research, a four-item questionnaire for mothers was composed and administered, which inquired about perceptions of the utility value of mathematics and science in their children's life. Answers were on a scale ranging from 1 (not useful) to 5 (very useful). Similarly, two items assessed, from the adolescents' perspective, the importance value that parents attributed to mathematics and science for the adolescents' life. Finally, the adolescents' perception about the value of math and science for their futures was measured with four items focusing on the current and future value of mathematics and science for themselves.

When items written for the current investigation have not been used, task value has generally been measured with global instruments that assess learning strategies and motivation. Within scales measuring different motivational constructs, a subscale assessing task value is typically included (for example, Gargallo, Suárez-Rodríguez, \& Pérez-Pérez, 2009). Among these instruments, the most widely used is the Motivated Strategies for Learning Questionnaire (Pintrich, Smith, Garcia, \& McKeachie, 1991), which has numerous adaptations in other languages, such as Spanish (Burgos Castillo \& Sánchez Abarca, 2012; Donolo, Chiecher, Paoloni, \& Rinaudo, 2008; Ramírez Dorantes, Canto y Rodríguez, Bueno Alvarez, \& Echazarreta Moreno, 2013; Roces, Tourón, \& González, 1995), Turkish (Karadeniz, Büyüköztürk, Akgün, Çakmak, \& Demirel, 2008) and Iranian (Nasiriyan, Azar, Noruzy, \& Dalvand, 2011). Although a recent meta-analysis (Credé \& Phillips, 2011) provides empirical evidence about the theoretical structure of MSLQ, its task value scale assesses perceptions of interest (e.g., I am very interested in the content of this course), importance (e.g., It is important for me to learn the course material) and utility (e.g., I think I'll be able to use what I learn in this course in other cours$e s$ ) as one single dimension. Every aspect of task value 
is evaluated by two items, totaling six items that are averaged to calculate an overall score of task value.

Eccles and colleagues (Eccles \& Wigfield, 1995; Eccles, Wigfield, Harold, \& Blumenfeld, 1993; Eccles et al., 1983; Wigfield et al., 1997) developed and validated instruments to specifically measure the components of interest, importance and utility comprised in the task value construct as defined in their model. The instruments are domain specific and assess, for example, how children value different academic courses and extracurricular activities such as sports. Each scale has three items, and the full set of items is found in Eccles et al. (1993) and Wigfield et al. (1997). Also, Eccles et al. (1983) measured the perceived cost of math and language for students, with items that asked how much time these activities took off the spare time they could spend in other activities (Wigfield \& Cambria, 2010). Recently, Kosovich, Hulleman, Barron and Getty (2014) validated a scale of expectancy-value-cost that evaluates a new conceptualization (Barron \& Hulleman, 2015) on the expectancy-value models of motivation. The value factor consists of three items assessing importance, interest and utility, while cost is assessed by four items. Thus, the three classic components (importance, interest, utility) are merged into one factor, which in turn is separated from the cost factor.

There are other instruments that measure specific interest in a subject (Marsh, Köller, Trautwein, Lüdtke, \& Baumert, 2005), the importance of different domains (Harter, 1986) or perceptions regarding utility and interest of classes in college students (Hulleman, Durik, Schweigert, \& Harackiewicz, 2008).

McCoach and Siegle (2002) designed an instrument including twenty-two items, called Class Value Assessment, to measure three aspects of task value based on the theoretical model of task value by Eccles and Wigfield. Specifically, it evaluates importance, interest and utility in two versions: mathematics and language arts. The instrument has good properties of internal validity and reliability as measured by exploratory factor analysis, and internal consistency.

As shown, task value measurement has been carried out in a one-dimensional fashion integrating some aspects of the construct in a single scale, or developing items and scales assessing a partial set of components. This type of measurement involves theoretical and applied limitations, as it does not allow to distinguish among components, differentiate the type of relationship they have with other constructs, or discriminate the effects of interventions focusing on some of its components.

An exception to this is the work of Lou et al. (2012), who constructed and validated a scale for measuring task value in Taiwanese college students (the Achievement Task Value Scale for University Students). It is worth stressing that the scale was developed on the basis of the expectancy-value theory proposed by Eccles and Wigfield (2002) and Wigfield and Eccles (1992).

\section{The Achievement Task Value Scale for University Students}

Lou et al. (2012) built and validated the Achievement Task Value Scale to measure task value for Taiwanese college students. The instrument consists of thirty-eight items measuring four components of task value: importance (ten items), interest (nine items), utility (ten items) and cost (nine items). The importance scale evaluates perceptions about the relationship between task and identity (e.g., Academic learning has effects on college students' future). The interest scale assesses enjoyment related to success in a task (e.g., University classes are much more interesting and diverse than classes in high school). The utility scale assesses congruence among tasks, career goals, and potential future benefits (e.g., Academic knowledge gained in university can be used when I graduate and enter the labor market). The cost scale evaluates the perceived costs of engaging in a task with a successful outcome (e.g., If you want to be successful in university, you have to spend time and energy).

In order to assess internal validity of the Academic Task Value Scale, Lou et al. (2012) conducted two confirmatory factor analyses (maximum likelihood method) with an estimation sample and a validation sample, specifying a model of four related factors. Both the estimation sample (CFI $=.98$, RMSEA $=0.064$, SRMR $=0.055)$ and the validation sample $(\mathrm{CFI}=.98$, $\mathrm{RMSEA}=$ 0.057 , SRMR $=0.049$ ) showed a good model fit. Furthermore, in both samples high factor loadings (.54 to .85) and good composite reliability levels (.87 to .93 ) were obtained. Finally, all four components showed high or very high correlations with each other in both the estimation sample (.68 to .88 ) and the validation sample $(.79$ to .90$)$.

This paper analyzes the psychometric properties of the Achievement Task Value Scale for University Students in a sample of Argentinian students. 
Specifically, evidence of internal, convergent, and criterion validity, and internal consistency are provided.

\section{Method}

\section{Participants}

A convenience sample of five hundred sixty-three Argentinian undergraduates ( $81 \%$ female, $19 \%$ male; $\mathrm{M}=25.02$ years, $\mathrm{SD}=6.66$; grade point average $\mathrm{M}=6.41, \mathrm{SD}=1.49$ ) from a large national university participated, belonging to thirteen different departments, with a predominance of Psychology students (55\%). These students attended their university programs from first to fifth year.

\section{Instruments}

The Achievement Task Value Scale (Lou et al., 2012) that evaluates importance (e.g., Academic performance will influence the future of a university student, $\alpha=.88$ ), interest (e.g., Participating in class makes subjects more interesting, $a=.87$ ), utility (e.g., Subjects are useful because they can improve our knowledge and professional skills, $\alpha=.91$ ) and cost (e.g., In order to obtain the benefits of learning, we need to make an effort , $\alpha=.92) \mathrm{com}$ ponents was used. Students expressed their degree of agreement with each item by using a Likert scale ranging from 1 to 7 (0\% to $100 \%$ agreement).

Task value. The one-dimensional task value scale by Pintrich et al. (1993) was used, to evaluate perceived interest, importance and utility regarding learning materials and contents, and consists of six items (e.g., I think what I learn in this course will be useful in others, original $\alpha=.90$ ). The items are answered using a Likert scale, expressing the degree of agreement, from (1) Strongly disagree to (5) Strongly agree. This scale demonstrated criterion validity regarding achievement emotions in university students from Argentina (Sánchez-Rosas, Piotti, Sánchez, Pereira, \& Debat, 2011). One-dimensionality and internal consistency yielded acceptable results in this study (кмо $=.84,49 \%$ explained variance, and factor loadings $>.60, \alpha=.79$ ).

Academic enjoyment. Academic enjoyment, understood as the enjoyment experienced by attending class, studying and taking exams, was also evaluated. A modified version of Achievement Emotions Questionnaire-Argentine (AEQ-AR, Sánchez-Rosas, 2015a) scales was used, to assess enjoyment of attending class, studying and taking exams. The scale consisted of eleven items (e.g., I am looking forward to the next class). Students expressed how often they experience enjoyment, in a Likert scale ranging from (1) Never to (5) Always. One-dimensionality and internal consistency yielded acceptable results in this study ( $\mathrm{KMO}=$ $.78,36 \%$ explained variance, and factor loadings $>.44$, $\alpha=.81)$.

Achievement goals. Approach mastery goals were evaluated through three items (e.g., My goal is to learn as much as possible) with the Argentinean Achievement Goal Questionnaire - Revised (Sánchez-Rosas, 2015b). The items are answered using a Likert scale, expressing the degree of agreement, from (1) Strongly disagree, to (5) Strongly agree. One-dimensionality and internal consistency yielded acceptable results in this study (кмо $=.70,69 \%$ explained variance, and factor loadings $>.79, \alpha=.78$ ).

Attention in class. An ad hoc drafted one-dimensional scale that evaluates ability of concentration, irrelevant thoughts, and attention was used to measure attention in class. It comprised three items (e.g., I can easily concentrate). The items are answered based on a Likert scale ranging from (1) Never, to (5) Always. It is a one-dimensional scale with acceptable internal consistency (кмо $=.70,67 \%$ explained variance, and factor loadings $>.77, \alpha=.75$ ).

\section{Procedure}

First, items were translated from Chinese to Spanish by a professional translator, so that items had a clear, accurate and simple wording and kept the original meaning of the construct they intend to assess; changes were also made to some expressions not commonly used in Spanish. The response format was adapted to evaluate the degree of agreement with each item on a scale ranging from (1) Strongly disagree to (7) Strongly agree. A protocol was formulated comprising instruments, and questions about gender, age, academic unit, year of coursework and grade point average including failed marks. The protocol was administered to the sample through an online survey system. All participants were informed about the study objectives, and anonymity and confidential data processing were guaranteed. Students voluntarily agreed to participate.

\section{Data Analysis}

Obtained data was loaded to sPss and AMOs, and data analyses relevant to the study objectives were conducted using these programs.

Prior to the central analysis, items were explored in order to find missing values, outliers — both 
univariate and multivariate-, normal distribution and multicollinearity (George \& Mallery, 2007). Univariate outliers were identified by calculating $\mathrm{z}$ scores for each variable (z score > 3.29), and multivariate outliers were detected by applying Mahanalobis distance $(p<.001)$. To check assumptions of normality of the sample, skewness and kurtosis in each item were analyzed. Values of skewness and kurtosis ranging between +2 and -2 were considered acceptable (George \& Mallery, 2007). Items' multicollinearity was estimated using bivariate Pearson correlations, considering values of $\mathrm{r}<.90$ as appropriate.

In order to analyze internal validity, an exploratory and confirmatory strategy was implemented by conducting an exploratory and confirmatory factor analysis. This decision was made because, in the original studies (Lou et al., 2012), all four components had high or very high correlations among them. Moreover, correlated measurement errors took place. Overall, this could involve an overlap and artifice that could be affecting the reported results.

Therefore, the sample was randomly divided into two parts trying to complete the minimum requirements of participants per item, and then estimation and validation samples were obtained. Thus, an exploratory factor analysis was performed with the estimation sample $(\mathrm{N}=342)$ to assess the structure underlying the set of items (Pérez \& Medrano, 2014). Specifically, the guidelines for factor analysis recommended by Fabrigar, Wegener, MacCallum and Strahan (1999) were followed. Principal axis method for factor extraction was used, and because the underlying factors might be interrelated, a method of oblique rotation (promax) was used. Multiple criteria were used for factor selection: (a) the eigenvalues-greater-than-one rule proposed by Kaiser (Kaiser, 1960), (b) scree plot (Cattell, 1966), (c) parallel analysis (Horn, 1965), (d) the percentage of variance explained by the obtained factor structure (cumulative variance of the factors extracted together) is at least $50 \%$ of the total variability of response to test (Merenda, 1997), and (e) interpretation of the rotated factors. Finally, as an additional criterion it was decided that those items with item-factor correlations $>.40$ were retained.

A confirmatory factor analysis was performed with the validation sample $(\mathrm{N}=221)$ to contrast the specified theoretical model which was based on results of the exploratory factor analysis (Arias, 2008). Following recommendations of Hoyle and Panter (1995), model's goodness-of-fit was diagnosed with multiple criteria. Chi-square/degrees of freedom ratio values (CMIN / DF), comparative fit index (CFI), goodness-of-fit index (GFI), and root mean square error of approximation (RMSEA) were considered. Goodness-of-fit values were interpreted as follows: $\chi 2 / \mathrm{df} \leq 2$ (Hair, Black, Babin, \& Anderson, 2010); CFI and GFI $>.95$, RMSEA $<.06$ was considered a good fit; CFI and GFI $>.90$, RMSEA $<.08$ was acceptable; and RMSEA from .08 to .10 was mediocre (Byrne, 2009).

Internal consistency was then estimated using Cronbach's alpha coefficient. An alpha coefficient of .70 was interpreted as acceptable, .80 as good and .90 as excellent (George \& Mallery, 2007). An item shall only be removed if values of internal consistency are improved as a result.

In order to justify the use of a coefficient, the tau-equivalence of items was evaluated using the congeneric model as the baseline (Dunn, Baguley, \& Brunsden, 2014). Changes in indexes of fit were evaluated, both the CFI ( $\Delta$ CFI > -.01; Cheung, \& Rensvold, 2002) and the RMSEA $(\triangle$ RMSEA $<.015$; Chen, 2007) report on the relevance of considering factor loadings as statistically similar within each factor evaluated. That is, it is expected that adjustment indices do not differ much between the congeneric model and the tau-equivalent. In addition to a coefficient, their confidence intervals (CI; Domínguez-Lara, 2016) were calculated using the ICalfa module (Domínguez-Lara, \& Merino-Soto, 2015). Finally, in all cases, reliability of the latent variable was estimated using the $\omega$ coefficient (McDonald, 1999).

To assess convergent validity, bivariate relationships between the resulting scales and another one-dimensional scale of task value (Sánchez-Rosas et al., 2011) were analyzed. For this purpose, correlations among variables were calculated using Pearson's $r$ coefficient. It was expected that scores in the one-dimensional task value scale correlated at least moderately and positively with scores in the resultant task value scales.

As task value is related to other constructs that help to explain the reasons why individuals prioritize or not certain academic activities (Wigfield \& Eccles, 2000), consequences are expected on student engagement in class (Fredricks et al., 2004). To provide evidence of criterion validity, relations between the resultant task value scales and enjoyment, approach mastery goals and attention were explored. To this end, correlations among variables were calculated using Pearson's $r$ coefficient. As evidenced by some studies, enjoyment (Pekrun et al., 2011; Sánchez-Rosas et al., 2016b), approach mastery goals (Liem et al., 2008) and attention (Pekrun et al., 
2010; Sánchez-Rosas \& Esquivel, 2016; Sánchez-Rosas et al., 2016a) were expected to correlate positively with resultant task value scales.

\section{Results}

No missing values, univariate or multivariate outliers, nor multicollinearity were detected. Skewness and kurtosis values $(<2)$ were adequate (George \& Mallery, 2007), showing normal distribution of the items.

An initial examination of items' correlations was performed, and it was found that some items did not correlate with the items on its own scale. For example, items 1 (Academic performance will influence the future of a university student) and 4 (Subject activities are a student's duty and obligation) do not reflect the importance of subjects, classroom activities, and learning to improve students' knowledge level. Instead, they refer to the final outcome of activities (academic performance) and a quality assigned to tasks, without reference to the benefit of the knowledge level. Items 13 (I find subjects useful for the future), 14 (University classes are much more interesting and diverse than classes in high school) and 20 (I like to learn new things in class) do not entirely reflect the interest or pleasure related to subjects, classroom activities, and learning. They even combine interest and utility and compare features of lessons in two different educational levels.

In addition, it was noted that items 8 (The GPA obtained in my undergraduate program will affect my job search) and 9 (When looking for a job, a good GPA will improve my chances in relation to other people) had very high correlations with another items, showing an unnecessary overlap in the items' content.

Because it is an assumption of exploratory factor analysis that items are related and show no multicollinearity, these seven items were removed and internal structure was analyzed with the thirty-one remaining items.

\section{Validity Based on Internal Structure and Reliability}

Exploratory factor analysis and internal consistency. Based on multiple criteria suggested for data analysis, three factors $(\mathrm{KMO}=.91)$ that accounted for $46 \%$ of the variance were extracted. However, five items (5 - To commit myself to subject activities, makes me responsible for the career I chose; 12 - A positive attitude toward learning can enhance interest in learning; 18 - I like teachers who teach in a dynamic and interesting way: 30 - Studying before and after school can be useful for you to learn skills that you would not have otherwise acquired; 40 - What is taught in university is very diverse and, though now I do not know its application, it might be useful in the future) showed item-factor correlations $<.40$ and one item (33 - In order to learn well, I need to take initiative in classes) presented simultaneous correlations with two factors. These items were removed and a new exploratory factor analysis was performed.

Once more, multiple criteria were contemplated for data analysis and the extraction of three rotated factors was specified. This final factor solution $(\mathrm{KMO}=.92)$ comprised three interrelated factors that accounted for $51 \%$ of the variance. All items showed item-factor correlations $>.40$. Factor 1 ended up being composed of fourteen items which originally belonged to the importance and utility scales. A content analysis of the translated items, which originally belonged to the importance scale and now comprise factor 1 along with other items from utility scale, quite clearly reflected typical aspects of utility value. As a consequence, factor 1 was called Utility. Factor 2 was composed of seven items related to cost and was called Cost. Finally, factor 3 was composed of four items related to interest and was called Interest. Factor correlation matrix showed that utility correlated positively with cost $(\mathrm{r}=.55)$ and interest $(\mathrm{r}=.23)$; while cost correlated positively with interest $(r=.18)$. Due to the low magnitude of some of these correlations among components, the correlations of the three scales were also explored by computing the observed scores of each item. In this case, correlation values were found to be slightly higher. Specifically, utility correlated positively with cost $(\mathrm{r}=.55)$ and interest $(\mathrm{r}=.24)$; while cost correlated positively with interest $(r=.25)$. Although in both estimates the correlations obtained were low in some cases, the results evidenced by the factorial structure are positively considered (variance percentage, factor loadings). This factorial structure is tested later with the validation sample.

In this sample, the utility and cost scales showed acceptable levels of internal consistency assessed by the Cronbach's alpha coefficient, although the interest scale showed a marginally acceptable value. Table 1 shows the results of the exploratory factor analysis with eigenvalues, variance percentage, factor loadings and internal consistency. 
Table 1

Factorial Structure and Internal Consistency with the Estimation Sample

\begin{tabular}{|c|c|c|c|}
\hline & Utility & Cost & Interest \\
\hline it 2. Subjects improve my skills and increase my knowledge & .78 & & \\
\hline it 3. Classes may improve our professional knowledge & .75 & & \\
\hline it 6. Finishing university studies will help me acquire a certain level of knowledge & .46 & & \\
\hline it 7. Classes may help to expand my professional knowledge & .83 & & \\
\hline it 10. Learning thoroughly what is explained in classes may improve my professional skills and knowledge & .59 & & \\
\hline it 11. Participating in class makes subjects more interesting & & & 62 \\
\hline it 15 . I like reflections and debates that take place in the classes & & & .72 \\
\hline it 16. I like cooperation and interpersonal communication when we carry out group activities & & & .72 \\
\hline it 17 . Everyday life-related topics are interesting & & & .53 \\
\hline it 21 . The more I learn, the better prepared I will be to enter the labor market & .48 & & \\
\hline it 22. University classes may improve our knowledge & .71 & & \\
\hline it 23. Subjects are useful because they may improve our professional skills and knowledge & .73 & & \\
\hline it 24 . Professional knowledge acquired at university will be useful for work & .75 & & \\
\hline it 25 . University studies are useful for my professional future & .52 & & \\
\hline it 26. What I learn at university will be useful when I start specialized studies & .66 & & \\
\hline it 27 . What I learn at university will be useful when starting my professional life & .74 & & \\
\hline it 28. Learning modality at university is useful in order to acquire knowledge & .68 & & \\
\hline it 29. In subjects, besides acquiring professional knowledge, you can also learn useful skills for the future & .59 & & \\
\hline it 31 . In order to have success in activities proposed in the subjects, I need to sacrifice some of my time & & .71 & \\
\hline it 32 . In order to learn properly, I need to make an effort & & .84 & \\
\hline it 34 . In order to learn properly, I need to change negative attitudes or bad habits towards studying & & .73 & \\
\hline it 35. It is worth studying for subjects I find interesting & & .58 & \\
\hline it 36. In order to obtain the benefits of learning, we need to make an effort & & .83 & \\
\hline it 37. It is worth spending time studying and obtaining good grades in exams & & .62 & \\
\hline it 39. It is worth making an effort in order to study properly, because it will be useful in the future & & .58 & \\
\hline Eigenvalue & 8.47 & 2.33 & 1.86 \\
\hline$\%$ of variance explained by each factor & 33.89 & 9.33 & 7.44 \\
\hline Cronbach's a & .91 & .84 & .65 \\
\hline
\end{tabular}

Note. $\mathrm{N}=342$. The values represent factor loadings. (Numbers indicate ordered items in protocols).

\section{Confirmatory factor analysis and internal consistency}

A confirmatory factor analysis was performed in order to examine the three-factor model obtained by exploratory factor analysis. As in this case, the presence of a large number of items per scale often leads to difficulties in obtaining good model fit (Nasser \& Takahashi, 2003). The use of item parcels in Structural Equation Modeling (SEM) has become quite common in recent years (Bandalos, 2002; Little, Cunningham, Shahar, \& Widaman, 2002; Little, Rhemtulla, Gibson, \& Schoemann, 2013). Parceling involves summing or averaging item scores from two or more items and using these parcel scores in place of the item scores in a SEM analysis (Bandalos, 2002; Little et al., 2002). In this way, the plots reduce complexity and number of parameters to estimate, adding or averaging groups of items that are conceptually similar and belong to a single dimension (Little et al., 2002). In this research, items with asymmetry of opposite signs have been parceled, which makes variance distribution of analyzed elements more uniform (Little et al., 2002; 2013). We parceled items of utility (four parcels) and cost (four parcels) scales, and used the items of the interest scale unchanged. 
Thus, a three-related-factor model was evaluated, in which each factor explained the behavior of their specified four elements.

The model showed good fit to the data $[(51, \mathrm{~N}=$ 221) $=99.75, \mathrm{p}=.001, \chi 2 / \mathrm{df}=1.96, \mathrm{CFI}=.96, \mathrm{GFI}=.93$, RMSEA $=0.066]$ with high factor loadings ( $\mathrm{p} \leq .001)$.

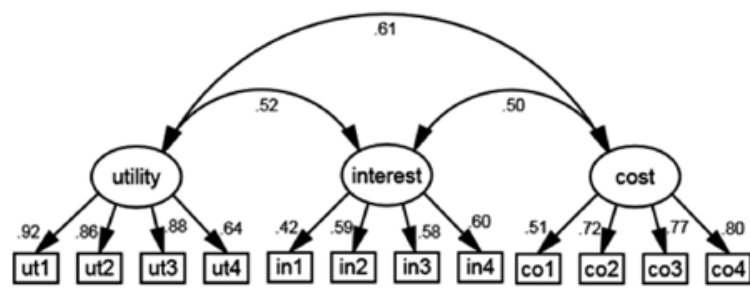

Figure 1. Three-related-factor model for the Achievement Task Value Scale. Estimates are standardized. Error variables are not represented in order to simplify presentation.
When considering the three factors analyzed, only the interest factor does not meet the assumption of tau-equivalence, so it would be advisable to consider the $\omega$ coefficient. In this sample, utility, interest, and cost scales showed excellent, good and acceptable levels of internal consistency, respectively.

\section{Validity Based on Relations with Other Variables}

\section{Test-criterion relationships and convergent evidence}

To obtain additional evidence of validity, the individual scores of the items that comprise each scale were added together and bivariate correlations were calculated. Table 3 shows bivariate correlations

Table 2

Tau-Equivalence of Items and Scale Reliability

\begin{tabular}{|c|c|c|c|c|c|c|c|}
\hline & & CFI & RMSEA & (CI 95\%) & $\alpha$ & CI $95 \% \alpha$ & $\omega$ \\
\hline \multirow[t]{3}{*}{ Utility } & Congeneric & .865 & .091 & $(.077-.105)$ & .910 & $.884-.930$ & .912 \\
\hline & Tau-equivalence & .840 & .092 & $(.079-.105)$ & & & \\
\hline & $\Delta$ & -.025 & .001 & & & & \\
\hline \multirow[t]{3}{*}{ Interest } & Congeneric & 1.000 & .000 & $(.000-.079)$ & .611 & $.521-.688$ & .627 \\
\hline & Tau-equivalence & .899 & .079 & $(.017-.137)$ & & & \\
\hline & $\Delta$ & .101 & .079 & & & & \\
\hline \multirow[t]{3}{*}{ Cost } & Congeneric & .864 & .107 & $(.076-.140)$ & .811 & $.760-.852$ & .815 \\
\hline & Tau-equivalence & .866 & .089 & $(.061-.117)$ & & & \\
\hline & $\Delta$ & .002 & -.018 & & & & \\
\hline
\end{tabular}

Note. $\mathrm{N}=221 . \alpha=$ alpha coefficient, $\mathrm{CI}=$ confidence intervals, $\omega=$ omega coefficient.

Table 3

Convergent and Criterion Validity among Task Value, Enjoyment, Achievement Goals and Attention

\begin{tabular}{|c|c|c|c|c|c|c|c|c|}
\hline & 1 & 2 & 3 & 4 & 5 & 6 & 7 & 8 \\
\hline 1. Utility & - & & & & & & & \\
\hline 2. Interest & $.43^{* *}$ & - & & & & & & \\
\hline 3. Cost & $.55^{* *}$ & $.36^{* *}$ & - & & & & & \\
\hline 4. Value (p’s.) & $.54^{* *}$ & $.39^{* *}$ & $.41^{* *}$ & - & & & & \\
\hline 5. Enjoyment & $.43^{* *}$ & $.37^{* *}$ & $.23^{* *}$ & $.48^{* *}$ & - & & & \\
\hline 6. Mastery approach & $.35^{* *}$ & $.26^{* *}$ & $.41^{* *}$ & $.55^{* *}$ & $.46^{* *}$ & - & & \\
\hline 7. Attention & $.24^{* *}$ & $.11^{*}$ & $.14^{*}$ & $.34^{* *}$ & $.43^{* *}$ & $.33^{* *}$ & - & \\
\hline 8. GPA & .07 & .07 & .09 & .11 & $.14^{*}$ & .01 & $.19^{*}$ & - \\
\hline
\end{tabular}

Note. $\mathrm{N}=221,{ }^{\star} p<.05,{ }^{* *} p<.01$, value (P’s.) = value (Pintrich's scale), GPA = Grade Point Average. 
between the three task-value scales and task value, enjoyment, mastery approach goals, attention, and grade point average (Table 3). Moderate correlations between task value scales and enjoyment and mastery approach goals provide favorable evidence of convergent validity and test criteria. However, the relationship between the three scales of task value and attention was low; on the other hand, the task value scale of Pintrich et al. (1993) was moderately involved with attention. Finally, only enjoyment and attention correlated lowly with grade point average.

\section{Discussion}

The work initiated by Jacqueline Eccles and her colleagues on the expectancy-value model of motivation has provided researchers in Educational Psychology with a framework to understand students' choices in educational contexts (Eccles et al., 1983).

Students' engagement in academic activities requires important reasons for involvement, besides positive expectancies of success. In fact, Trautwein and colleagues (2012; Nagengast et al., 2011) found empirical evidence that interaction between expectancy and value has an effect on engagement in science activities, intentions to choose careers in science, and academic performance. These findings suggest that students with high expectancy and high value perform better than those with high levels only in one of these aspects, or low levels in both of them (Hulleman, Barron, Kosovich, \& Lazowski, 2016). Among these important reasons to get involved, task value allows answering the question: Why does a student want to engage in an achievement task? (Wigfield \& Cambria, 2010).

Task value is a multidimensional construct (Eccles et al., 1983) of proven relevance to achievement motivation literature due to its influence on learning processes and outcomes (Wigfield \& Cambria, 2010), as well as for its individual and contextual multi-determination (Eccles, 2005). It is precisely this multi-determination which allows evaluating interventions and programs that promote motivation, and particularly task value (for a meta-analytic review, see Lazowski \& Hulleman, 2015), transcending correlation research. It is important to remark that such intervention studies, in manipulating variables and investigating their causal effects, allow making recommendations for educational practice based on appropriate scientific evidence (Hulleman et al., 2016).
A limitation on intervention studies, and also on correlation studies, at least in our literature review, is that there is a lack of instruments allowing measuring the four components of task value in a discriminated and simultaneous way. However, the Achievement Task Value Scale (Lou et al., 2012) would be the exception, as it evaluates the importance, utility, interest, and cost components of task value.

This study aimed to evaluate the psychometric properties of this instrument in a sample of Argentine university students. An exploratory and confirmatory strategy was used to support validity evidence based on the internal structure. In order to support validity evidence based on relations with other variables, test-criterion relationships and convergent evidence were analyzed. Scales' convergence was assessed by matching them with a one-dimensional task value scale (Pintrich et al., 1993). Evidence of scales' criterion validity was provided testing their relations with enjoyment, achievement goals and attention. Finally, internal consistency was estimated using Cronbach's alpha and omega coefficients. Results support the assertion that this version of the instrument allows to assess, in a reliable and valid way, the utility, interest, and cost components of task value.

\section{Validity Based on Internal Structure and Reliability}

\section{Exploratory and confirmatory factor analysis}

Although the original version assessed a four related factor model with good fitting values, Lou et al. (2012) reported that there were many correlated measurement errors, and even the correlation among latent factors was very high. As this could have been the reason for getting successful results, the exploratory strategy used here intended to test how items freely related.

Indeed, preliminary exploration of items showed that the importance scale, which was more homogeneous informing on the importance activities have to improve the knowledge level, presented problems related to the items' content. Addressing both the final outcome of activities and some qualities assigned to tasks, and presenting content-redundancy were examples of those problems. Something similar happened with the interest scale.

After meeting the basic assumptions of exploratory factor analysis and considering the criteria for 
factor extraction, we have reached a three related factor structure, with satisfactory factor loadings, which accounted for a large proportion of variance. Items that were not adequately explained by the factors were not retained. Probably the extensive wording of some items may have affected the students' response. Lack of clarity and structure of some items could have also affected the response. Problems concerning clarity, extension, or understanding should be addressed in subsequent studies that seek to determine, for example through personal interviews, the cognitive processes concerning item response. Despite these problems, the obtained solution was clear and partially satisfactory, as identified factors allow measuring the utility, interest, and cost components of task value. The main reason for failing to identify the importance factor could be that, at least in our adaptation, its items failed to properly reflect the task's importance for self-identity. Indeed, it is clear that those items relate to the long- or short-term benefits of activities, which is typical of the utility component of task value.

Only after identifying the internal structure using exploratory factor analysis, the factor solution obtained was tested. A confirmatory factor analysis was performed in order to determine whether a theoretical three-related-factor model adequately fit the data. Additionally, since the large number of items in the utility and cost factors could affect model's fit (Nasser \& Takahashi, 2003), a method for parceling items was followed (Little et al., 2002; 2013). The model showed a good fit to the data with high factor loadings and consequently an instrument is available in which each factor explains the behavior of each of its four items. Correlations of interest with cost and utility were slightly higher than in the estimation sample, and this could be due to parceling of items. In this research, items with asymmetry of opposite signs have been parceled, which makes variance distribution of analyzed elements more uniform (Little et al., 2002; 2013).

\section{Internal consistency}

Moreover, in the estimation sample as well as the validation sample, measurement performed with the three scales showed good levels of internal consistency, and all items contributed to obtaining higher values of measurement homogeneity. It is noteworthy that internal consistency was estimated by computing the individual items, and not the parcels. Thus, the number of items in utility and cost scales could contribute to their high reported values. By contrast, the small number of items in the interest scale would contribute to hardly acceptable internal consistency values. This psychometric aspect of scales requires consideration in future research, for example, the disproportion of items per scale, the limited practicality in implementing large scales, as well as the need to improve homogeneity of the interest scale.

\section{Validity Based on Relations with Other Variables}

\section{Test-criterion relationships and convergent evidence}

Correlations obtained between each of the scales and the additional variables explored provided evidence of criterion and convergent validity. As it might be expected, the highest correlation values are among utility, interest and costs; and the one-dimensional task value scale (Pintrich et al., 1993), demonstrating convergent validity. Moreover, the hypothesized positive correlations between the three task value scales and enjoyment, approach mastery goals and attention were effectively found. So when students perceive tasks as useful to improving their knowledge, when they perceive them as interesting or enjoyable, even if they make a positive evaluation of the sacrifice required by the tasks, enjoyment increases, as well as adoption of approach mastery goals and focusing of attention. These results are in line with those of other studies that explored the relationship between task value and enjoyment (Pekrun et al., 2011; Sánchez-Rosas et al., 2016b), approach mastery goals (Liem et al., 2008) and attention (Pekrun et al., 2010; Sánchez-Rosas et al., 2016a). It should be noted that the magnitude of attention relationships with the three task value scales was low, and that these three scales did not demonstrate correlations with academic performance.

\section{Conclusions, Limitations and Further Studies}

Overall, the results of this research should be interpreted with caution and further studies should be performed. This work makes an important contribution to the emerging research on task value with university students in Argentina. At present, there is a wide range of instruments that psychologists and 
educational professionals use to measure different constructs. However, we must contribute to the educational research area that could sometimes fail to capture the motivation of students and their assessments about the various tasks that are offered to them. It is worth mentioning that the implementation of this research involved the challenge of adapting an instrument on the basis of a language quite different from Spanish, with more than enough obstacles to overcome; and an additional effort of rigor and dedication. Added to this, it is customary to treat motivation from a Western perspective. Consequently, openness to a different culture was necessary, forcing the search for common factors and ideas that transcend one culture or another. Given the structural difference found, it would be necessary to invest further efforts in testing an instrument that validly captures the four constructs of task value in populations from different countries and cultures. To do this, multi-group factor analysis could be used, establishing whether there is multi-factorial invariance among groups from different countries and cultures (Sass, 2011).

An important limitation of this study is related to the sample and sampling method, since there is a very high presence of women and the participants were included through a non-probabilistic sampling. This restricts the possibility of generalizing the results, so it should be a matter of balancing the presence of women and men and ensuring random sampling methods.

As mentioned, problems concerning clarity, extension, or understanding of some items may have affected the students' response. In addition, in order to measure the importance construct, items failed to properly reflect the task's importance for self-identity. So, issues related to evidence based on test content or evidence based on response processes should be considered, for example, through experts' judgment, interviews to students, and other methods to support validity evidence.

On the other hand, the use of parcels is not free of controversies and different stances for and against have been reported in the literature (see Little et al., $2002 ; 2013)$. New studies of internal validity could be carried out on the basis of items that capture all four components of task value, exploring the interrelationships of items, and using confirmatory factor analysis to test a theoretical model assessing four latent factors without parcels.
Although correlations between scales and other criteria were theoretically consistent, low or no relations with attention and academic performance must be addressed again. These two variables are often considered learning outcomes that are mediated by other psychological processes, such as emotions. Probably, the components of task value influence enjoyment, and then it influences attention and performance. The bivariate relationships found would be indicating this probable relationship, although more robust statistical analysis should be used. For example, structural equation models could be used to test theoretical predictions, regarding task value as a causal variable. Thus, the $a$ priori nature of predictions would allow stronger inferences (Curran, West, \& Finch, 1996).

Beyond these issues, the resultant task value scales have psychometric properties of validity and reliability for measuring the utility, interest, and cost components. These scales can be used in explanatory studies in order to analyze simultaneous relations of task value with other constructs. They can also be used in studies on motivational intervention seeking to develop task value or any of the components evaluated by these scales.

\section{References}

Acee, T. W., \& Weinstein, C. E. (2010). Effects of a ValueReappraisal Intervention on Statistics Students' Motivation and Performance. The Journal of Experimental Education, 78, 487-512. doi:10.1080/00220970903352753

Arias, B. (2008). Desarrollo de un ejemplo de Análisis Factorial Confirmatorio con LISREL, AMOS y SAS. Seminario de Actualización en Investigación sobre Discapacidad SAID 2008. Universidad de Valladolid.

Atkinson, J. W. (1957). Motivational determinants of risk taking behavior. Psychological Review, 64, 359-372.

Bandalos, D. L. (2002). The Effects of Item Parceling on Goodness-of-Fit and Parameter Estimate Bias in Structural Equation Modeling. Structural Equation Modeling: A Multidisciplinary Journal, 9(1), 78-102. doi:10.1207/ s15328007sem0901_5

Barron, K. E., \& Hulleman, C. S. (2015). Expectancy-value-cost model of motivation. In J. S. Eccles \& K. Salmelo-Aro (Eds.), International encyclopedia of social and behavioral sciences: Motivational psychology (2nd Ed.) (pp. 503-509). New York, NY: Elsevier. doi:10.1016/ b978-0-08-097086-8.26099-6 
Burgos Castillo, E., \& Sánchez Abarca, P. (2012). Adaptación $y$ validación preliminar del cuestionario de motivación $y$ estrategias de aprendizaje. Tesis para optar al título de Psicólogo/a, Escuela de Psicología, Universidad del BíoBío.

Byrne, B. M. (2009). Structural equation modeling with AMOs: Basic concepts, applications, and programming (2ndEd.), Mahwah, NJ: Lawrence Erlbaum. doi: 10.4324/9780203805534

Cattell, R. B. (1966). The Scree Test for the number of factors. Multivariate Behavioral Research, 1(2), 245-276. doi:10.1207/s15327906mbr0102_10

Chen, F. F. (2007). Sensitivity of goodness of fit indexes to lack of measurement invariance. Structural Equation Modeling, 14, 464-504. doi: 10.1080/10705510701301834

Cheung, G. W., \& Rensvold, R. B. (2002). Evaluating goodness-of-fit indexes for testing measurement invariance. Structural Equation Modeling, 9, 233-255. doi: 10.1207/S15328007SEM0902_5

Credé, M., \& Phillips, L. A. (2011) A meta-analytic review of the Motivated Strategies for Learning Questionnaire. Learning and Individual Differences, 21(4), 337-346. doi:10.1016/j.lindif.2011.03.002

Curran, P. J., West, S. G., \& Finch, J. F. (1996). The robustness of test statistics to non-normality and specification error in confirmatory factor analysis. Psychological Methods, 1(1), 16-29. doi:10.1037/1082-989X.1.1.16

Domínguez-Lara, S. (2016). Intervalos de confianza en el reporte de la fiabilidad: un análisis necesario. Anales del Sistema Sanitario de Navarra, 39(1), 169-170. doi: 10.23938/S1137-6627/2016000100024

Domínguez-Lara, S., \& Merino-Soto, C. (2015). ¿Por qué es importante reportar los intervalos de confianza del coeficiente alfa de Cronbach? Revista Latinoamericana de Ciencias Sociales, Niñez y Juventud, 13(2), 1326-1328.

Donolo, D., A. Chiecher, A., Paoloni, P., \& Rinaudo, M. C. (2008). MSLQe-MSLQvv. Motivated Strategies Learning Questionnaire. Propuestas para la medición de la motivación y el uso de estrategias de aprendizaje. EFUNARC, Río Cuarto.

Dunn, T. J., Baguley, T., \& Brunsden, V. (2014). From alpha to omega: A practical solution to the pervasive problem of internal consistency estimation. British Journal of Psychology, 105(3), 399-412. doi: 10.1111/bjop.12046

Durick, A. M., Hulleman, C. S., \& Harackiewicz, J. M., (2014). One Size Fits Some: Instructional Enhancements to Promote Interest, Mathematics and Science Learning. Washington, DC: American Educational Research Association.
Eccles, J. S. (1987). Gender roles and women's achievement related decisions. Psychology of Women Quarterly, 11, 135-172. doi:10.1111/j.1471-6402.1987.tb00781

Eccles, J. S. (2005). Subjective task value and the Eccles et al. model of achievement-related choices. In A. J. Elliot \& C. S. Dweck (Eds.), Handbook of competence and motivation (pp. 105-121). New York, NY: Guilford Press.

Eccles J. S., Adler, T. F., Futterman, R., Goff, S. B., Kaczala, C. M., Meece, J. L., \& Midgley, C. (1983). Expectancies, values, and academic behaviors. In J. T. Spence (Ed.), Achievement and achievement motivation (pp. 75-146). San Francisco, CA: Freeman.

Eccles, J. S., \& Wigfield, A. (1995). In the mind of the actor: The structure of adolescents' achievement task values and expectancy-related beliefs. Personality and Social Psychology Bulletin, 21, 215-225. doi: $10.1177 / 0146167295213003$

Eccles, J. S., \& Wigfield, A. (2002). Motivational beliefs, values and goals. Annual Review of Psychology, 53, 109132. doi: 10.1146/annurev.psych.53.100901.135153

Eccles, J. S., Wigfield, A., Harold, R., \& Blumenfeld, P. B. (1993). Age and gender differences in children's selfand task perceptions during elementary school. Child Development, 64, 830-847. doi: 10.2307/1131221

Elliot, A. J. (1999). Approach and avoidance motivation and achievement goals. Educational Psychologist, 34, 149-169. doi: 10.1207/s15326985ep3403_3

Elliot, A. J., \& Fryer, J. W. (2008). The goal construct in psychology. In J. Shah \& W. Gardner (Eds.), Handbook of motivational science. New York: Guilford Press.

Fabrigar, L. R., Wegener, D. T., MacCallum, R. C., \& Strahan, E. J. (1999). Evaluating the use of exploratory factor analysis in psychological research. Psychological Methods, 4(3), 272-299. doi: 10.1037/1082-989X.4.3.272

Fredricks, J. A., Blumenfeld, P. C., \& Paris, A. H. (2004). School engagement: Potential of the concept, state of the evidence. Review of Educational Research, 74, 59-109. doi:10.3102/00346543074001059

Gargallo, B., Suárez-Rodríguez, J. M., \& Pérez-Pérez, C. (2009). El cuestionario CEVEAPEU. Un instrumento para la evaluación de las estrategias de aprendizaje de los estudiantes universitarios. RELIEVE, 15(2), 1-31.

George, D., \& Mallery, P. (2007). spss for Windows: Step by step 14.0 update (7th Ed.). Boston: Allyn \& Bacon.

Hair, J. F., Black, W. C., Babin, B. J., \& Anderson, R. E. (2010). Multivariate Data Analysis: A Global Perspective, (7th Ed.), Pearson, Upper Saddle River: NJ. 
Harackiewicz, J. M., Rozek, C. S., Hulleman, C. S., \& Hyde, J. S. (2012). Helping Parents to Motivate Adolescents in Mathematics and Science: An Experimental Test of a Utility-Value Intervention. Psychological Science, 3, 1-8. doi: 10.1177/0956797611435530

Harter, S. (1986). Manual for the self-perception profile for adolescents. Denver: University of Denver.

Hidi, S., \& Baird, W. (1986). Interestingness-A neglected variable in discourse processing. Cognitive Science, 10, 179-194. doi: 10.1207/s15516709cog1002_3

Horn, J. L. (1965). A rationale and test for the number of factors in factor analysis. Psychometrika, 30(2), 179185. doi: 10.1007/BF02289447

Hoyle, R., \& Panter, A. (1995). Writing about structural equation models. In R. Hoyle (Ed.), Structural equation modeling: Concepts, issues, and applications (pp. 100-119). Thousand Oaks, CA: Sage.

Hulleman, C. S., Barron, K. E., Kosovich, J. J., \& Lazowski, R. A. (2016). Student Motivation: Current theories, constructs, and interventions within an expectancy value framework. In A. A. Lipnevich, F. Preckel, \& R. D. Roberts (Eds.), Psychosocial skills and school systems in the twenty-first century: Theory, research, and applications (pp. 241-278). Basel: Springer. doi: 10.1007/9783-319-28606-8_10

Hulleman, C. S., Durik, A. M., Schweigert, S. A., \& Harackiewicz, J. M. (2008). Task values, achievement goals, and interest: An integrative analysis. Journal of Educational Psychology, 100, 398-416. doi: 10.1037/00220663.100.2.398

Hulleman, C. S., Godes, O., Hendricks, B. L., \& Harackiewicz, J. M. (2010). Enhancing interest and performance with a utility value intervention. Journal of Educational Psychology, 102, 880-895. doi: 10.1037/a0019506

Hulleman, C. S., \& Harackiewicz, J. M. (2009). Promoting Interest and Performance in High School Science Classes. Science, 326, 1409-1412. doi: 10.1126/science.1177067

Hulleman, C. S., Kosovich, J. J., Barron, K. E., \& Daniel, D. B. (2016). Making Connections: Replicating and Extending the Utility Value Intervention in the Classroom. Journal of Educational Psychology. Advance online publication. doi: http://dx.doi.org/10.1037/ edu0000146

Jones, S. H., Johnson, M. L., \& Campbell, B. D. (2015). Influence of task-values, engagement, and attention allocation on conceptual change. Contemporary Educational Psychology, 42, 62-70. doi:10.1016/j.cedpsych.2015.04.004
Kaiser, H. F. (1960). The application of electronic computers to factor analysis. Educational and Psychological Measurement, 20, 141-151. doi: 10.1177/ 001316446002000116

Karadeniz, S., Büyüköztürk, S., Akgün, Ö E., Çakmak, E. K., \& Demirel, F. (2008). The Turkish adaptation study of motivated strategies for learning questionnaire (MSLQ) for 12-18 year old children: results of confirmatory factor analysis. The Turkish Online Journal of Educational Technology, 7, 108-117.

Kosovich, J. J., Hulleman, C. S., Barron, K. E., \& Getty, S. (2014). A Practical Measure of Student Motivation: Establishing Validity Evidence for the Expectancy-Value-Cost Scale in Middle School. The Journal of Early Adolescence, 35(5-6), 790-816. doi:10.1177/0272431614556890

Lazowski, R. A., \& Hulleman, C. S. (2015). Motivation Interventions in Education: A Meta-Analytic Review. Review of Educational Research, 85(2), 602-640. doi:10.3102/0034654315617832

Lee Johnson, M., \& Sinatra, G. M. (2013). Use of task-value instructional inductions for facilitating engagement and conceptual change. Contemporary Educational Psychology, 38, 51-63. doi: 10.1016/j.cedpsych.2012.09.003

Liem, A. D., Lau, S., \& Nie, Y. (2008). The role of self-efficacy, task value, and achievement goals predicting learning strategies, task disengagement, peer relationship, and achievement outcome. Contemporary Educational Psychology, 33, 486-512. doi:10.1016/j.cedpsych.2007.08.001

Little, T. D., Cunningham, W. A., Shahar, G., \& Widaman, K. F. (2002). To parcel or not to parcel: Exploring the question, weighing the merits. Structural Equation Modeling, 9, 151-173. doi:10.1207/S15328007SEM0902_1

Little, T. D., Rhemtulla, M., Gibson, K., \& Schoemann, A. M. (2013). Why the items versus parcels controversy needn't be one. Psychological Methods, 18(3), 285-300. doi:10.1037/a0033266

Lou, Y. C., Lin, H. F., \& Lin, C. W. (2012). Development and Confirmatory Factory Analysis of the Achievement Task Value Scale for University Students. Journal of Psychoeducational Assessment, 31(5), 482-492.

Marsh, H. W., Köller, O., Trautwein, U., Lüdtke, O., \& Baumert, J. (2005). Academic self-concept, interest, grades, and standardized test scores: Reciprocal effects models of causal ordering. Child Development, 76, 397-416. doi: 10.1111/j.1467-8624.2005.00853.x

McCoach, D. B., \& Siegle, D. (2002). A pilot validation of the class value assessment. Paper presented at the Annual Meeting of the American Psychological Association, Chicago, IL. 
McDonald, R. P. (1999). Test theory: A unified treatment. Mahwah, N. J.: L. Erlbaum Associates.

Merenda, P. (1997). A guide to the proper use of Factor Analysis in the conduct and reporting of research: pitfalls to avoid. Measurement and evaluation in counseling and evaluation, 30, 156-163.

Miller, R. B., \& Brickman, S. A. (2004). A model of future oriented motivation and self-regulation. Educational Psychology Review, 16, 9-33. doi: 10.1023/B:EDPR.0000012343.96370.39

Nagengast, B., Marsh, H. W., Scalas, L. F., Xu, M. K., Hau, K. T., \& Trautwein, U. (2011). Who took the " $\mathrm{x}$ " out of expectancy-value theory? A psychological mystery, a substantive-methodological synergy, and a cross-national generalization. Psychological Science, 22(8), 1058-1066. doi: 10.1177/0956797611415540

Nasiriyan, A., Azar, H. K., Noruzy, A., \& Dalvand M. R. (2011). A model of self-efficacy, task value, achievement goals, effort and mathematics achievement. International Journal of Academic Research, 3(2), 612-618.

Nasser, F., \& Takahashi, T. (2003). The effect of using item parcels on ad hoc goodness-of-fit indexes in confirmatory factor analysis: An Example using Sarason's reactions to tests. Applied Measurement in Education, 16(1), 75-97. doi: 10.1207/S15324818AME1601_4

Pang, B. (2014). Promoting physical activity in Hong Kong Chinese young people: Factors influencing their subjective task values and expectancy beliefs in physical activity. European Physical Education Review, 20(3), 385-397. doi:10.1177/1356336x14534360

Pekrun, R. (2006). The control-value theory of achievement emotions: Assumptions, corollaries and implications for educational research and practice. Educational Psychology Review, 18, 315-341. doi:10.1007/s10648006-9029-9

Pekrun, R., Goetz, T., Daniels, L. M., Stupinsky, R. H., \& Perry, R. P. (2010). Boredom in achievement settings: exploring Control-Value antecedents and performance outcomes of a neglected emotion. Journal of Educational Psychology, 102(3), 531-549. doi: 10.1037/ a0019243

Pekrun, R., Goetz, T., Frenzel, A. C., Barchfeld, P., \& Perry, R. P. (2011). Measuring emotions in students' learning and performance: the achievement emotions questionnaire (AEQ). Contemporary Educational Psycholo$g y, 36,36-48$. doi:10.1016/j.cedpsych.2010.10.002
Pérez, E., \& Medrano, L. (2014). Exploratory factor analysis: conceptual and methodological basis. Revista Argentina de Ciencias del Comportamiento, 6(3), 71-80.

Pintrich, P. R., Smith D. A. F., García, T., \& McKeachie, W. J. (1991). A manual for the use of the Motivated Strategies for Learning Questionnaire (MSLQ). Ann Arbor: Michigan, National Centre for Research to Improve Postsecondary Teaching and Learning.

Pintrich, P. R., Smith, D. A. F., Garcia, T., \& McKeachie, W. J. (1993). Reliability and predictive validity of the motivated strategies for learning questionnaire (MSLQ). Educational and Psychological Measurement, 53, 810 814. doi:10.1177/0013164493053003024

Ramírez Dorantes, M. C., Canto y Rodríguez, J. E., Bueno Álvarez, J. A., \& Echazarreta Moreno, A. (2013). Validación Psicométrica del Motivated Strategies for Learning Questionnaire. Electronic Journal of Research Educational Psychology, 29, 193-214.

Roces, C., Tourón, J., \& González, M. C. (1995). Validación del CEAM II (Cuestionario de Estrategias de Aprendizaje y Motivación). Psicológica, 16(3), 347-366. Retrieved from http://dadun.unav.edu/bitstream/10171/19176/1/Validaci\%C3\%B3n\%20preliminar\%20del\%20CEAM\%20II.pdf

Rozek, C. S., Hyde, J. S., Svoboda, R. C., Hulleman, C. S., \& Harackiewicz, J. M. (2014). Gender differences in the effects of a utility-value intervention to help parents motivate adolescents in mathematics and science. Journal of Educational Psychology, 107(1), 195-206. doi: $10.1037 / \mathrm{a} 0036981$

Sánchez-Rosas, J. (2015a). The Achievement Emotions Questionnaire-Argentine (AEQ-AR): internal and external validity, reliability, gender differences and norm-referenced interpretation of test scores. Evaluar, 15, 41-74.

Sánchez-Rosas, J. (2015b). Validation of the Achievement Goal Questionnaire - Revised in Argentinean university students (A-AGQ-R). International Journal of Psychological Research, 8(1), 10-23.

Sánchez-Rosas, J., \& Bedis, J. (2015). Measuring Strategies to Cope with Boredom in Spanish Speaking Population: A Study with Argentinian University Students. Evaluar, 15, 99-122.

Sánchez-Rosas, J. \& Esquivel, S. (2016). Instructional Teaching Quality, Task Value, Self-Efficacy, and Boredom: A Model of Attention in Class. Revista de Psicología, 25(2), 1-20. doi: http://dx.doi.org/10.5354/07190581.2017 .44966 
Sánchez-Rosas, J., \& Pérez, E. (2015). Measuring threats, benefits, emotional costs and avoidance of academic help seeking in Argentinian university students. Pensamiento Psicológico, 13(2), 49-64. doi:10.11144/javerianacali.ppsi13-2.mtbe

Sánchez-Rosas, J., Piotti, A., Sánchez, V., Pereira, A., \& Debat, E. (2011). Implicancias del interés, la importancia y la utilidad de los materiales y contenidos de aprendizaje para las emociones académicas. Presented at the III Congreso de Psicología de la Facultad de Psicología de la Universidad Nacional de Córdoba, Argentina. doi: 10.13140/2.1.4317.9526

Sánchez-Rosas, J., Takaya, P. B., \& Molinari, A. V. (2016a). Atención en clase: rol predictivo del comportamiento docente, valor de la tarea, autoeficacia, disfrute y vergüenza. Psiencia. Revista Latinoamericana de Ciencia Psicológica, 8(3). doi: 10.5872/psiencia/8.3.22

Sánchez-Rosas, J., Takaya, P. B., \& Molinari, A. V. (2016b). The Role of Teacher Behavior, Motivation and Emotion in Predicting Academic Social Participation in Class. Pensando Psicología, 12(19), 39-53. doi: 10.16925/ pe.v12i19.1327

Sass, D. A. (2011). Testing measurement invariance and comparing latent factor means within a confirmatory factor analysis framework. Journal of Psychoeducational Assessment, 29(4), 347-363. doi:10.1177/0734282911406661

Schiefele, U. (1999). Interest and Learning from Text. Scientific Studies of Reading, 3(3), 257-279. doi:10.1207/ s1532799xssr0303_4

Schukajlow, S., Leiss, D., Pekrun, R., Blum, W., Müller, M., \& Messner, R. (2012). Teaching methods for modelling problems and students' task-specific enjoyment, value, interest and self-efficacy expectations. Educational Studies in Mathematics, 79(2), 215-237. doi: 10.1007/ s10649-011-9341-2.
Trautwein, U., Marsh, H. W., Nagengast, B., Lüdtke, O., Nagy, G., \& Jonkmann, K. (2012). Probing for the multiplicative term in modern expectancy-value theory: A latent interaction modeling study. Journal of Educational Psychology, 104(3), 763-777. doi: 10.1037/a0027470

Wigfield, A. (1994). Expectancy-value theory of achievement motivation: A developmental perspective. Educational Psychology Review, 6, 49-78. doi: 10.1007/ BF02209024

Wigfield, A., \& Cambria, J. (2010). Students' achievement values, goal orientations, and interest: Definitions, development, and relations to achievement outcomes. Developmental Review, 30, 1-15. doi: 10.1016/j. dr.2009.12.001

Wigfield, A., \& Eccles, J. S. (1992). The development of achievement task value: A theoretical analysis. Developmental Review, 12, 265-310. doi: 10.1016/02732297(92)90011-P

Wigfield, A., \& Eccles, J. S. (2000). Expectancy-value theory of achievement motivation. Contemporary Educational Psychology, 25, 68-81. doi: 10.1006/ceps.1999.1015

Wigfield, A., \& Eccles, J. S. (2002). The development of competence beliefs, expectancies for success, and achievement values from childhood through adolescence. In A. Wigfield \& J. S. Eccles (Eds.), Development of achievement motivation (pp. 91-120). San Diego, CA: Academic Press.

Wigfield, A., Eccles, J. S., Yoon, K. S., Harold, R. D., Arbreton, A., Freedman-Doan, C., et al. (1997). Changes in children's competence beliefs and subjective task values across the elementary school years: A three-year study. Journal of Educational Psychology, 89, 451-469. 